Case Report

\title{
Immune Checkpoint Inhibition as Primary Adjuvant Therapy for an IDH1-Mutant Anaplastic Astrocytoma in a Patient with CMMRD: A Case Report-Usage of Immune Checkpoint Inhibition in CMMRD
}

\author{
Rebekah Rittberg ${ }^{1, *,+}+$, , Craig Harlos ${ }^{1}$, Heidi Rothenmund ${ }^{2}$, Anirban Das ${ }^{3}$, Uri Tabori ${ }^{3}$, \\ Namita Sinha ${ }^{4}\left(\mathbb{D}\right.$, Harminder Singh ${ }^{5}$, Bernie Chodirker ${ }^{2}$ and Christina A. Kim ${ }^{1,6}$ \\ 1 Section of Hematology/Oncology, Department of Internal Medicine, Rady Faculty of Health Sciences, \\ University of Manitoba, Winnipeg, MB R3E 0V9, Canada; charlos@cancercare.mb.ca (C.H.); \\ ckim3@cancercare.mb.ca (C.A.K.) \\ 2 Department of Biochemistry and Medical Genetics, Max Rady College of Medicine, University of Manitoba, \\ Winnipeg, MB R3E 0J9, Canada; hrothenmund@hsc.mb.ca (H.R.); BChodirker@hsc.mb.ca (B.C.) \\ 3 Division of Hematology/Oncology, The Hospital for Sick Children, Department of Pediatrics, University of \\ Toronto, Toronto, ON M5G 1X8, Canada; anirban.das@sickkids.ca (A.D.); uri.tabori@sickkids.ca (U.T.) \\ 4 Department of Pathology, Rady Faculty of Health Sciences, University of Manitoba, \\ Winnipeg, MB R3E 3P5, Canada; nsinha@sharedhealthmb.ca \\ 5 Section of Gastroenterology, Department of Internal Medicine, Rady Faculty of Health Sciences, \\ University of Manitoba, Winnipeg, MB R3A 1R9, Canada; Harminder.singh@umanitoba.ca \\ 6 Research Institute in Oncology and Hematology, CancerCare Manitoba, Winnipeg, MB R3E 0V9, Canada \\ * Correspondence: rrittberg@cancercare.mb.ca \\ + Current Address: 675 McDermot Ave, Winnipeg, MB R3E 0V9.
}

Received: 13 December 2020; Accepted: 21 January 2021; Published: 1 February 2021

check for updates

\begin{abstract}
Constitutional mismatch repair deficiency (CMMRD) is a rare autosomal recessive hereditary cancer syndrome due to biallelic germline mutation involving one of the four DNA mismatch repair genes. Here we present a case of a young female with CMMRD, homozygous for the c.2002A>G mutation in the PMS2 gene. She developed an early stage adenocarcinoma of the colon at the age of 14. Surveillance MRI of the brain at age 18 resulted in the detection of an asymptomatic brain cancer. On resection, this was diagnosed as an anaplastic astrocytoma. Due to emerging literature suggesting benefit of immunotherapy in this patient population, she was treated with adjuvant dual immune checkpoint inhibition, avoiding radiation. The patient remains stable with no evidence of progression 20 months after resection. The patient's clinical course, as well as the rational for considering adjuvant immunotherapy in patients with CMMRD are discussed in this report.
\end{abstract}

Keywords: constitutional mismatch repair deficiency; CMMRD; immunotherapy; adjuvant therapy; checkpoint inhibitors; screening; surveillance; tumor mutational burden

\section{Introduction}

Constitutional mismatch repair deficiency (CMMRD), first described in 1999 [1], is an autosomal recessive syndrome due to biallelic germline mutation involving one of the four DNA mismatch repair (MMR) genes (MLH1, MSH2, MSH6, or PMS2) [2,3]. The MMR genes play a critical role in correcting single base pair mismatch and short insertions/deletions, ensuring genome stability [4,5]. CMMRD is associated with high morbidity due to the onset of malignancies during childhood or early adulthood [6,7]. The most common CMMRD-related malignancies are hematologic and gastrointestinal 
cancers; however, other cancer types including endometrial, ovarian, urinary tract, and sarcomas have been described $[7,8]$.

The first malignancy in CMMRD is usually diagnosed within the first decade of life [7]. Brain tumors are common, occurring in 55\% of patients, with high grade glioma (HGG) being the predominant pathology, presenting at a mean age of diagnosis of nine years [9]. CMMRD patients may also have non-malignant manifestations, including café-au-lait macules, hypopigmentation, and immunoglobulin deficiencies [2,3,10]. Presentation varies based on the impacted MMR gene. Onset of first malignancy occurs later in patients with biallelic germline mutation of PMS2, with the mean age of first malignancy of 10 years, compared to 7.5 and 8 years for patients with biallelic loss of MSH6 and MLH1/MSH2, respectively [9,11]. Biallelic PMS2 mutation is also associated with a greater incidence of brain tumors, colorectal cancer (CRC), and endometrial carcinomas compared to biallelic mutations in $\mathrm{MLH1}, \mathrm{MSH} 2$, and $\mathrm{MSH} 6$ which have a proportionally higher rate of hematologic malignancies [7]. Cancer surveillance is a critical component of CMMRD management and a number of surveillance guidelines exist (Table 1) [6,11-13]. Variation between these protocols may be due to differences in the CMMRD population assessed when guidelines were published [6,11-13]. Whole body MRI (WBMRI) has emerged as a potentially useful screening tool $[6,12]$ and patient series suggest that WBMRI may improve early detection [14] and survival [15].

Table 1. European Consortium, Canadian and US Multi-society Task Force on Colorectal Cancer Constitutional mismatch repair deficiency (CMMRD) surveillance guidelines.

\begin{tabular}{|c|c|c|c|}
\hline Malignancies & European Consortium [11] & $\begin{array}{c}\text { Canadian Surveillance } \\
\text { Protocol }[6,12]\end{array}$ & $\begin{array}{c}\text { US Multi-Society Task Force } \\
\text { on Colorectal Cancer [13] }\end{array}$ \\
\hline Brain tumors & $\begin{array}{c}\text { MRI brain every } 6 \text { to } 12 \\
\text { months, starting at the age } \\
\text { of } 2\end{array}$ & $\begin{array}{l}\text { MRI brain at diagnosis } \\
\text { then every } 6 \text { months }\end{array}$ & $\begin{array}{l}\text { MRI brain every } 6 \text { months, } \\
\text { starting at the age of } 2\end{array}$ \\
\hline \multirow[t]{2}{*}{ Gastrointestinal tumors } & $\begin{array}{l}\text { Upper: annual video capsule } \\
\text { endoscopy and gastroscopy, } \\
\text { starting at the age of } 10\end{array}$ & $\begin{array}{l}\text { Upper: annual video } \\
\text { capsule endoscopy and } \\
\text { gastroscopy, starting } \\
\text { between } 4 \text { to } 6 \text { years }\end{array}$ & $\begin{array}{l}\text { Upper: annual video capsule } \\
\text { endoscopy and gastroscopy, } \\
\text { starting at the age of } 8\end{array}$ \\
\hline & $\begin{array}{l}\text { Lower: annual colonoscopy, } \\
\text { starting at the age of } 8\end{array}$ & $\begin{array}{l}\text { Lower: annual } \\
\text { colonoscopy, starting } \\
\text { between } 4 \text { to } 6 \text { years }\end{array}$ & $\begin{array}{l}\text { Lower: annual colonoscopy, } \\
\text { starting at the age of } 6\end{array}$ \\
\hline $\begin{array}{l}\text { Hematologic } \\
\text { malignancies }\end{array}$ & $\begin{array}{l}\text { Annual clinical examination } \\
\text { and CBC every } 6 \text { months, } \\
\text { starting at the age of } 1\end{array}$ & $\begin{array}{c}\text { Abdominal ultrasound } \\
\text { every } 6 \text { months, starting at } \\
\text { the age of } 1\end{array}$ & $\begin{array}{c}\text { CBC every } 6 \text { months, starting } \\
\text { at the age of } 1\end{array}$ \\
\hline Genitourinary tumors & $\begin{array}{l}\text { Annual urine cytology and } \\
\text { urine } \\
\text { dipstick, starting at the age } \\
\text { of } 20\end{array}$ & $\begin{array}{c}\text { Annual urine cytology and } \\
\text { urine } \\
\text { dipstick, starting at the age } \\
\text { of } 20\end{array}$ & $\begin{array}{c}\text { Annual urinalysis, starting at } \\
\text { the age of } 10\end{array}$ \\
\hline Gynecologic tumors & $\begin{array}{c}\text { Annual gynecologic } \\
\text { examination, transvaginal } \\
\text { ultrasounds, and } \\
\text { endometrial biopsy, starting } \\
\text { at the age of } 20\end{array}$ & $\begin{array}{c}\text { Annual gynecologic } \\
\text { examination, transvaginal } \\
\text { ultrasounds, and } \\
\text { endometrial biopsy, } \\
\text { starting at the age of } 20\end{array}$ & $\begin{array}{c}\text { Annual gynecologic } \\
\text { examination, transvaginal } \\
\text { ultrasounds, and endometrial } \\
\text { biopsy, starting at the age of } 20\end{array}$ \\
\hline
\end{tabular}

Abbreviations: $\mathrm{MRI}=$ magnetic resonance imaging, $\mathrm{CBC}=$ complete blood count.

As CMMRD is rare, with less than 200 cases reported in the literature, surveillance guidelines and optimal cancer treatment options are still evolving $[6,9,12]$. CMMRD is likely under recognized, and is likely more prevalent in endogamous population [16], highlighting the importance of maintaining a high clinical suspicion. Here we describe a case of a young female with CMMRD diagnosed with colon cancer and an IDH-mutant anaplastic astrocytoma (AA). To our knowledge, this is the first published 
case of a CMMRD associated IDH-mutant AA treated with adjuvant nivolumab and ipilimumab after resection, without adjuvant radiation.

\section{Case Description}

Here we present a case of a 19-year-old Inuit female who comes from a family known to have CMMRD following the diagnosis of gastric cancer in a sibling at age 11. Our patient underwent molecular testing at age 10, which confirmed she was homozygous for the c.2002A>G mutation in the PMS2 gene. This variant is classified as likely deleterious and has been described as a founder mutation in the Inuit population of northern Quebec [17]. She was included as part of that series.

The patient subsequently began surveillance gastroscopies and colonoscopies at age 11. At age 14, she was diagnosed with a pT2N0 moderately differentiated adenocarcinoma of the colon, treated with total colectomy. MMR immunohistochemistry showed loss of expression of PMS2 in both neoplastic epithelial and normal mesenchymal elements, a finding specific for CMMRD [3]. Since 2018, she has been followed in the Manitoba Hereditary Gastrointestinal Cancer Clinic, where surveillance recommendations were followed based on current guidelines [6,11-13].

On first surveillance brain MRI, at age 18, she was found to have a $2.6 \mathrm{~cm}$ mass-like area of FLAIR hyperintensity in the right frontal lobe (Figure 1). She underwent a craniotomy and resection of tumor. Pathology demonstrated a HGG with frequent mitosis but no definite endothelial proliferation and/or necrosis and she was diagnosed with AA, IDH1 R132H mutant, WHO grade 3, with immunohistochemistry results suggestive of biallelic PMS2 mutation (Figure 2). Immunohistochemistry was negative for BRAF V600E mutation and PD1/PDL1 expression. Whole exome sequencing identified a tumor mutational burden (TMB) of 8 mutations/Mb [18]. In addition to the IDH1 R132H mutation, a pathogenic variant in TP53 was detected (c.817C > T; p.Arg273Cys).

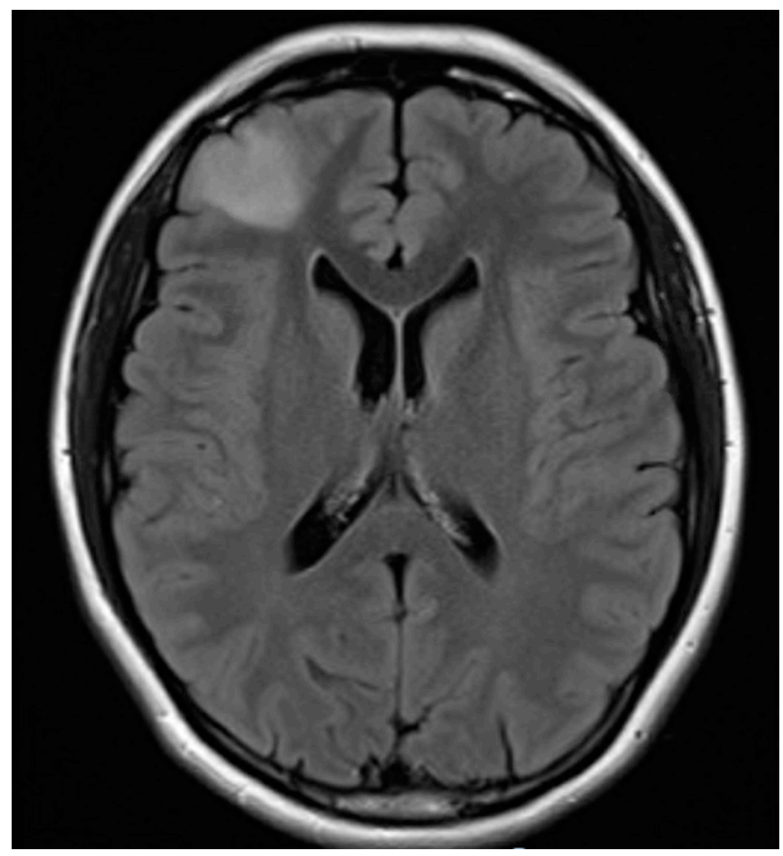

(A)

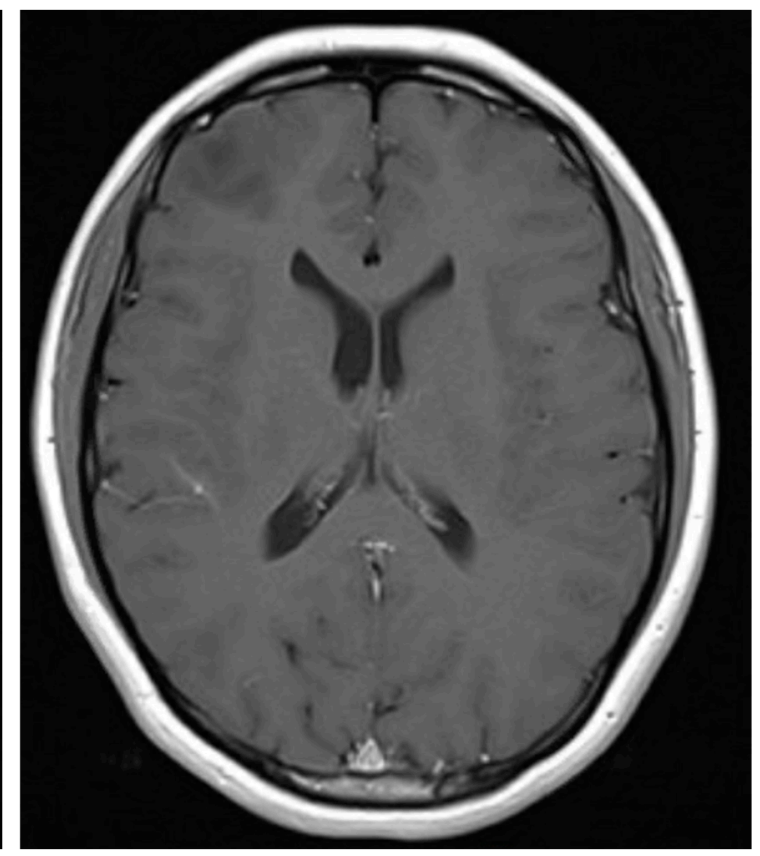

(B)

Figure 1. Cont. 


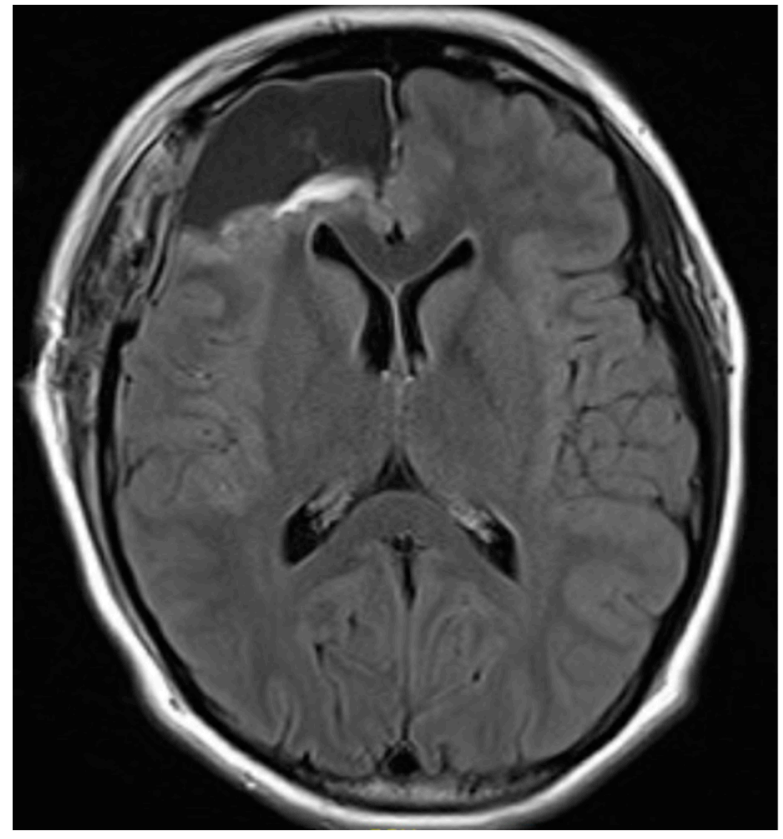

(C)

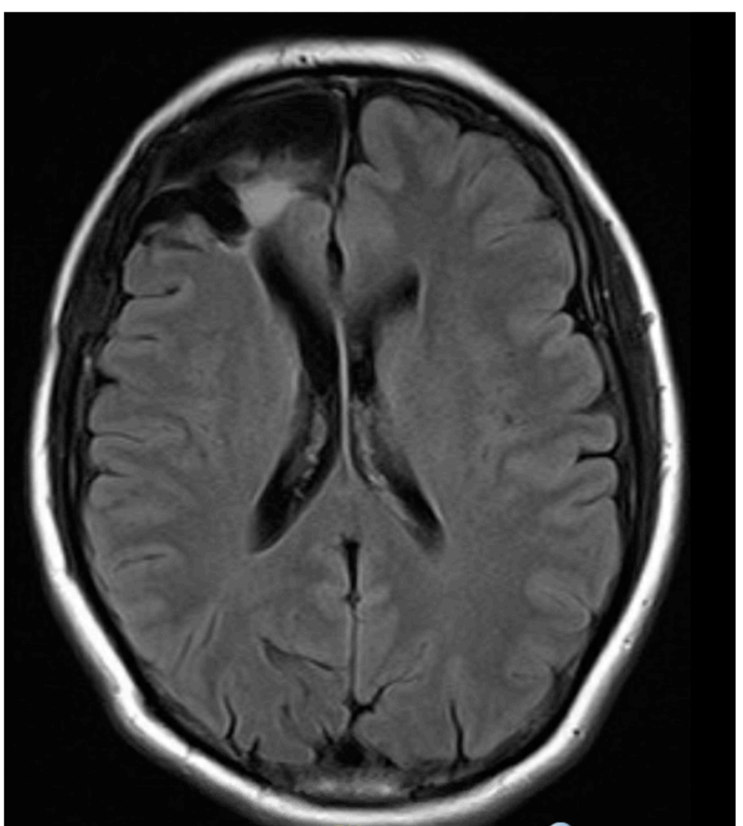

(D)

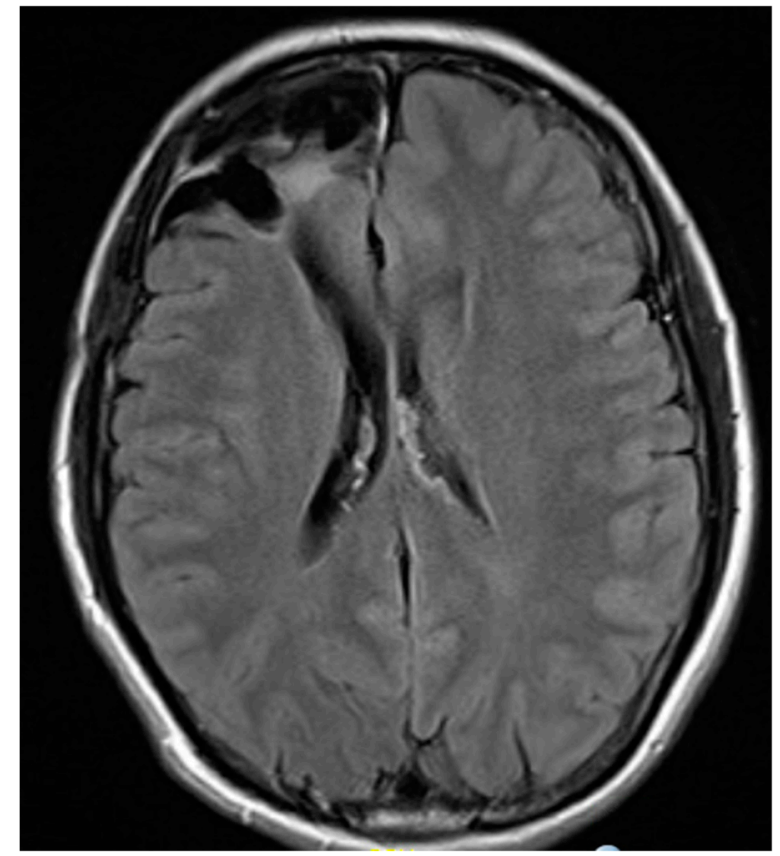

(E)

Figure 1. FLAIR sequence axial MRI brain images. (A) $2.6 \times 2.0 \mathrm{~cm}$ lesion in right frontal lobe (pre-operative). (B) T1 post contrast pre-operative image of right frontal lobe lesion (pre-operative) (C) Hyperintense blood products in resection bed (post-operative day 1), (D) Focal area of increased T2/FLAIR signal deep to resection cavity (prior to starting ICI, 9 months after resection). (E) T2/FLAIR hyperintense tissue changes in right frontal lobe appear stable (18 months post resection). 


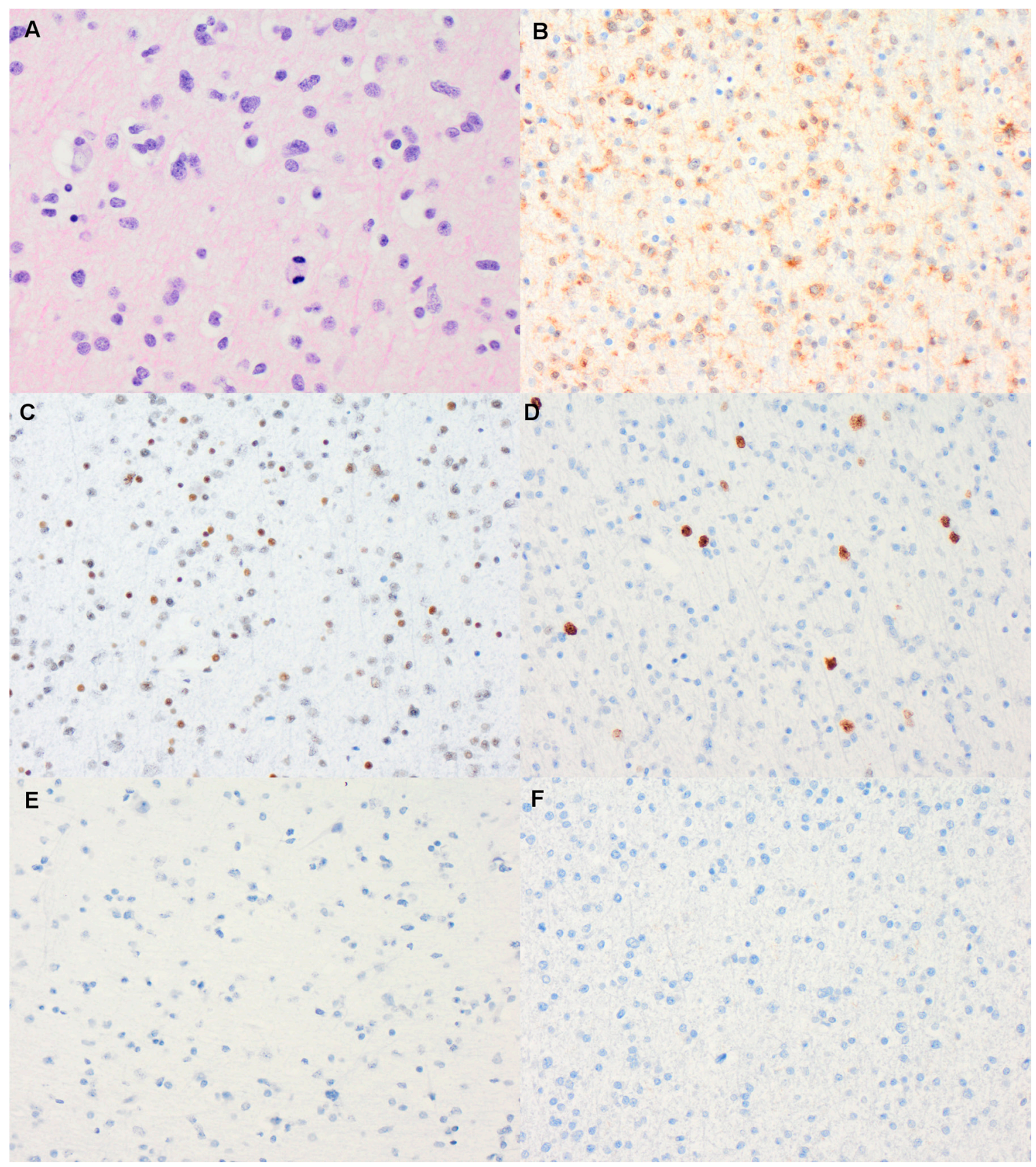

Figure 2. (A) Hematoxylin and eosin stain stained section showing an infiltrating anaplastic astrocytoma, composed of mitotically active astroglial cells with enlarged, hyperchromatic, irregular nuclei $(\times 400$ magnification). On immunohistochemistry, the tumor cells are positive for mutant IDH1 R132H (B); show loss of ATRX expression in tumor nuclei (C); a small subset of tumor nuclei expressing p53 (D); complete loss of PMS2 in both normal brain tissue and neoplastic astroglial cells (E); and absence of PDL1 expression (F) (all images at $\times 200$ magnification).

An MRI brain 12 weeks after surgical resection demonstrated a slight increase of the non-enhancing region deep to the resection cavity, suggestive of possible residual disease. There was new increased signal intensity on FLAIR along the superior and deep margin of the resection cavity. Because of the rarity of this condition, her case was discussed in a multidisciplinary fashion with experts across Canada. Emerging literature suggests that high-grade brain malignancies in children with CMMRD can demonstrate objective responses and prolonged survival following immune checkpoint inhibition (ICI) $[19,20]$. As such, she was offered adjuvant nivolumab and ipilimumab; however, 
treatment initiation was delayed for nine months due to pregnancy. Uninfused MRI brain was completed every 2-3 months during pregnancy, with a non-contrast MRI brain in the third trimester of pregnancy demonstrating slight increase in bulk of the FLAIR changes. These findings were stable on the post pregnancy MRI. Despite treatment delay, after delivery, adjuvant nivolumab (3 mg/kg) and ipilimumab $(1 \mathrm{mg} / \mathrm{kg}$ ) was administered every three weeks for four cycles, followed by maintenance nivolumab. After multidisciplinary discussion, as the possible residual disease had remained stable, the consensus was to forgo radiotherapy.

After cycle 1 of nivolumab and ipilimumab, she developed grade 1, clinically asymptomatic hyperthyroidism (TSH $<0.015$, free T3 44, free T4 $>100$ ). She was assessed by endocrinology, and the differential diagnosis was postpartum thyroiditis versus thyroid dysfunction secondary to immunotherapy (thyroperoxidase antibody was within normal limits at $18 \mathrm{IU} / \mathrm{mL}$ ). Immunotherapy continued with close monitoring of clinical symptoms and bloodwork with gradual improvement in her thyroid function tests. After cycle 4, she developed headache, decreased appetite, and fatigue. Bloodwork confirmed grade 2 hypothyroidism (TSH $>100$, free T3 < 1.0, free T4 1.0) and grade 2 adrenal insufficiency (random cortisol $38 \mathrm{nmol} / \mathrm{L}$ ). MRI showed immune-related hypophysitis. Maintenance nivolumab was held and she was treated with levothyroxine, as well as a tapering course of prednisone followed by replacement hydrocortisone. Hospitalization was not required. No other immune-related adverse events were experienced. A brain MRI demonstrated stable post-treatment changes prior to the re-initiation of maintenance nivolumab. Her MRI continues to show stability with no evidence of progression 20 months post-resection and 8 months post-hypophysitis.

\section{Discussion}

Gliomas are classified and graded based on histologic and molecular features. Grade 3 (AA) and 4 (glioblastoma) gliomas are classified as HGG. Standard treatment is dependent on these characteristics, with AA being treated with concurrent radiation and temozolomide followed by adjuvant temozolomide [21]. Pediatric HGG have a median overall survival of only 7-15 months despite multimodal treatment using surgical resection, radiation, and chemotherapy [22-24]. CMMRD-associated HGG are particularly aggressive cancers with a very poor prognosis. They are resistant to alkylating antineoplastic agents, including temozolomide which is frequently used in the treatment of HGG [25]. Further, continuous accumulation of mutations related to the germline defect make them rapidly refractory to conventional treatments. Specifically, IDH1 mutant MMR-deficient HGG have been documented to have a median OS of 15 months with conventional chemo-irradiation based approaches [26].

A recent report from an international consortium demonstrated that early detection of cancers using systematic surveillance can significantly improve survival in patients with CMMRD, including those with malignant brain tumors [15]. As CMMRD-related HGGs are aggressive and rapidly fatal malignancies, lead-time bias is unlikely to play a role in the actual reduction of mortality and improvement in survival following surveillance in these cancers. It is plausible that in the setting of background DNA mismatch repair deficiency, early detection and adequate surgical excision can prevent accumulation of additional deleterious mutations that develop in these tumors with time and prevent these cancers from developing a more aggressive phenotype [18,27]. However further prospective studies are required to delineate whether surveillance protocols consistently result in improved all-cause mortality in CMMRD. In our case, surveillance led to the early detection and treatment of both her asymptomatic gastrointestinal and CNS malignancies. Whether this will result in improved long term outcomes for our patient is not known, but highlights the importance of a multidisciplinary team, which can facilitate regular surveillance and implement appropriate treatment options.

In many areas of oncology, ICI have provided promise and dramatically altered the landscape in cancer treatments and outcomes, predominantly in tumors with high mutation burden, microsatellite-instability and/or an immune microenvironment [28,29]; however, the use of ICI in 
adult gliomas has not demonstrated satisfactory responses [30,31]. This is related to multiple factors, including lower mutation burden, acquiring mutations later in tumorigenesis, relative paucity of indels, poor neoantigen quality, high sub-clonality, and an immunosuppressed microenvironment in adult HGG [30,32]. In contrast, case reports in children with HGG and CMMRD have demonstrated favorable responses to ICI. AlHarbi et al. published a case of a five-year-old with CMMRD with an incurable HGG who experienced a durable treatment response of at least 10 months with nivolumab [33]. Bouffet et al. published a case series of two siblings with recurrent multifocal glioblastoma treated with ICI, with disease stability for 11 and 30 months post-recurrence [19,34]. The international consortium has recently reported on the impressive responses and survival of high-grade brain tumors in CMMRD using ICI [15]. These responses are possibly related to the early onset, and continuous accumulation [18] of high numbers of single nucleotide variants, total and microsatellite indels [35], which drive a robust immune response in this young cohort of patients with an underlying germline defect [29].

The KEYNOTE 158 study evaluated pembrolizumab in tumors with high mutational burden ( $\geq 10$ mutations/Mb) and found a $29 \%$ response rate, resulting in Food \& Drug Administration (FDA) approval of pembrolizumab for this indication in June 2020 [36]. Because our patient had a TMB of eight mutations $/ \mathrm{Mb}$, she would not have met this FDA indication. However, the cutoff for high TMB varies across tumor types $[37,38]$. The index tumor at the time of biopsy harbored eight mutations/ $\mathrm{Mb}$, which is much higher compared to the median mutation burden for pediatric high-grade brain tumors and gliomas ( $<1$ to 1.8 mutation/Mb) [39]. Though the current FDA approval for the use of Pembrolizumab proposes a TMB $>10$ mutations/ $\mathrm{Mb}$, there is increasing evidence that responses to ICI cannot be predicted by single biomarker cut-off [40]. Lombardi et al. completed a pilot study evaluating pembrolizumab in 13 adult patients with recurrent HGG with complete or partial loss of MMR protein expression showed a disease control rate of $31 \%$ and response to therapy did not correlate with degree of TMB [41]. However, pediatric HGG differ from adult HGG and an ongoing clinical trial is therefore prospectively evaluating the efficacy of ICI in pediatric tumors with mutation burden exceeding five mutations/Mb among other indications (NCT02992964) [42].

To our knowledge, we present the first case of a patient with a CMMRD associated HGG, detected at an asymptomatic stage using systematic surveillance, and treated using adjuvant nivolumab and ipilimumab following surgical resection. She is alive 20 months following her diagnosis. The prolonged survival following ICI is remarkable for a rapidly fatal and aggressive cancer. The additional opportunity to omit radiotherapy, thereby eliminating its late sequelae, may offer a new paradigm for management of these patients in the future.

Author Contributions: R.R. was responsible for completing the original manuscript draft. C.A.K., C.H., H.R., A.D., U.T., N.S., H.S. and B.C. contributed to development, review and editing of the manuscript. C.A.K. and R.R. were responsible for final manuscript review and approval of manuscript. C.H. provided images for Figure 1. N.S. provided images for Figure 2. All authors have read and agreed to the published version of the manuscript.

Funding: This work received no external funding.

Institutional Review Board Statement: The study was conducted according to the guidelines of the Declaration of Helsinki, and approved by the University of Manitoba research ethics board approval (H2020:299 (HS24039), approved on 15 June 2020).

Informed Consent Statement: Informed consent was obtained from the subject discussed in the case report.

Data Availability Statement: No new data were created or analyzed in this study. Data sharing is not applicable to this article.

Conflicts of Interest: Authors have no relevant conflict of interest. This original research has not been presented or published previously. 


\section{References}

1. Wang, Q.; Lasset, C.; Desseigne, F.; Frappaz, D.; Bergeron, C.; Navarro, C.; Ruano, E.; Puisieux, A. Neurofibromatosis and early onset of cancers in hMLH1-deficient children. Cancer Res. 1999, 59, $294-297$. [PubMed]

2. Wimmer, K.; Rosenbaum, T.; Messiaen, L. Connections between constitutional mismatch repair deficiency syndrome and neurofibromatosis type 1. Clin. Genet. 2017, 91, 507-519. [CrossRef] [PubMed]

3. Bakry, D.; Aronson, M.; Durno, C.; Rimawi, H.; Farah, R.; Alharbi, Q.K.; Alharbi, M.; Shamvil, A.; Ben-Shachar, S.; Mistry, M.; et al. Genetic and clinical determinants of constitutional mismatch repair deficiency syndrome: Report from the constitutional mismatch repair deficiency consortium. Eur. J. Cancer 2014, 50, 987-996. [CrossRef] [PubMed]

4. Liu, D.; Keijzers, G.; Rasmussen, L.J. DNA mismatch repair and its many roles in eukaryotic cells. Mutat. Res. Mutat. Res. 2017, 773, 174-187. [CrossRef] [PubMed]

5. Shiovitz, S.; Pritchard, C.C.; Jarvik, G.P. Lynch Syndrome: From Screening to Diagnosis to Treatment in the Era of Modern Molecular Oncology. Annu. Rev. Genom. Hum. Genet. 2019, 20, 293-307. [CrossRef]

6. Tabori, U.; Hansford, J.R.; Achatz, M.I.; Kratz, C.P.; Plon, S.E.; Frebourg, T.; Brugières, L. Clinical Management and Tumor Surveillance Recommendations of Inherited Mismatch Repair Deficiency in Childhood. Clin. Cancer Res. 2017, 23, e32-e37. [CrossRef]

7. Lavoine, N.; Colas, C.; Muleris, M.; Bodo, S.; Duval, A.; Entz-Werle, N.; Coulet, F.; Cabaret, O.; Andreiuolo, F.; Charpy, C.; et al. Constitutional mismatch repair deficiency syndrome: Clinical description in a French cohort. J. Med. Genet. 2015, 52, 770-778. [CrossRef]

8. Kratz, C.P.; Holter, S.; Etzler, J.; Lauten, M.; Pollett, A.; Niemeyer, C.M.; Gallinger, S.; Wimmer, K. Rhabdomyosarcoma in patients with constitutional mismatch-repair-deficiency syndrome. J. Med. Genet. 2009, 46, 418-420. [CrossRef]

9. Wimmer, K.; Kratz, C.P.; Vasen, H.F.; Caron, O.; Colas, C.; Entz-Werle, N.; Gerdes, A.-M.; Goldberg, Y.; Ilencikova, D.; Muleris, M.; et al. Diagnostic criteria for constitutional mismatch repair deficiency syndrome: Suggestions of the European consortium 'Care for CMMRD' (C4CMMRD). J. Med. Genet. 2014, 51, 355-365. [CrossRef]

10. Suerink, M.; Potjer, T.; Versluijs, A.; Broeke, S.W.T.; Tops, C.; Wimmer, K.; Nielsen, M. Constitutional mismatch repair deficiency in a healthy child: On the spot diagnosis? Clin. Genet. 2017, 93, 134-137. [CrossRef]

11. Vasen, H.F.; Ghorbanoghli, Z.; Bourdeaut, F.; Cabaret, O.; Caron, O.; Duval, A.; Entz-Werle, N.; Goldberg, Y.; Ilencikova, D.; Kratz, C.P.; et al. Guidelines for surveillance of individuals with constitutional mismatch repair-deficiency proposed by the European Consortium “Care for CMMR-D” (C4CMMR-D). J. Med. Genet. 2014, 51, 283-293. [CrossRef] [PubMed]

12. Durno, C.; Aronson, M.; Tabori, U.; Malkin, D.; Gallinger, S.; Chan, H.S.L. Oncologic surveillance for subjects with biallelic mismatch repair gene mutations: 10 year follow-up of a kindred. Pediatr. Blood Cancer 2011, 59, 652-656. [CrossRef] [PubMed]

13. Durno, C.; Boland, C.R.; Cohen, S.; Dominitz, J.A.; Giardiello, F.M.; Johnson, D.A.; Kaltenbach, T.; Levin, T.R.; Lieberman, D.; Robertson, D.J.; et al. Recommendations on Surveillance and Management of Biallelic Mismatch Repair Deficiency (BMMRD) Syndrome: A Consensus Statement by the US Multi-Society Task Force on Colorectal Cancer. Gastroenterology 2017, 152, 1605-1614. [CrossRef] [PubMed]

14. Aronson, M.; Gallinger, S.; Cohen, Z.; Cohen, S.; Dvir, R.; Elhasid, R.; Baris, H.N.; Kariv, R.; Druker, H.; Chan, H.; et al. Gastrointestinal Findings in the Largest Series of Patients with Hereditary Biallelic Mismatch Repair Deficiency Syndrome: Report from the International Consortium. Am. J. Gastroenterol. 2016, 111, 275-284. [CrossRef]

15. Ercan, A.; Durno, C.; Bianchi, V.; Edwards, M.; Aronson, M.; Scheers, I. Survival Benefit for Individuals with Constitutional Mismatch Repair Deficiency Syndrome Who Undergo a Surveillance Protocol: A Report from the International Replication Repair Deficiency Consortium. SIOP Abstr. Pediatr. Blood Cancer 2020, $67, \mathrm{e} 28742$.

16. Amayiri, N.; Tabori, U.; Campbell, B.; Bakry, D.; Aronson, M.; Durno, C.; Rakopoulos, P.; Malkin, D.; Qaddoumi, I.; Musharbash, A.; et al. High frequency of mismatch repair deficiency among pediatric high grade gliomas in Jordan. Int. J. Cancer 2015, 138, 380-385. [CrossRef] 
17. Li, L.; Hamel, N.; Baker, K.; McGuffin, M.J.; Couillard, M.; Gologan, A.; Marcus, V.; Chodirker, B.; Chudley, A.; Stefanovici, C.; et al. A homozygous PMS2 founder mutation with an attenuated constitutional mismatch repair deficiency phenotype. J. Med. Genet. 2015, 52, 348-352. [CrossRef]

18. Campbell, B.B.; Light, N.; Fabrizio, D.; Zatzman, M.; Fuligni, F.; De Borja, R.; Davidson, S.; Edwards, M.; Elvin, J.A.; Hodel, K.P.; et al. Comprehensive Analysis of Hypermutation in Human Cancer. Cell 2017, 171, 1042-1056.e10. [CrossRef]

19. Bouffet, E.; Larouche, V.; Campbell, B.B.; Merico, D.; De Borja, R.; Aronson, M.; Durno, C.; Krueger, J.; Cabric, V.; Ramaswamy, V.; et al. Immune Checkpoint Inhibition for Hypermutant Glioblastoma Multiforme Resulting from Germline Biallelic Mismatch Repair Deficiency. J. Clin. Oncol. 2016, 34, 2206-2211. [CrossRef]

20. Bouffet, E.; Sudhaman, S.; Chung, J.; Kelly, J.; Coblentz, A.; Edwards, M.; Lipman, T.; Zhang, C.; Ercan, A.B.; Sambira, L.; et al. IMMU-18. favorable outcome in replication repair deficient hypermutant brain tumors to immune checkpoint inhibition: An international rrd consortium registry study. Neuro Oncol. 2020, 22, iii363. [CrossRef]

21. Bent, M.J.V.D.; Baumert, B.; Erridge, S.C.; Vogelbaum, M.; Nowak, A.K.; Sanson, M.; Brandes, A.A.; Clement, P.M.; Baurain, J.F.; Mason, W.P.; et al. Interim results from the CATNON trial (EORTC study 26053-22054) of treatment with concurrent and adjuvant temozolomide for $1 \mathrm{p} / 19 \mathrm{q}$ non-co-deleted anaplastic glioma: A phase 3, randomised, open-label intergroup study. Lancet 2017, 390, 1645-1653. [CrossRef]

22. Mackay, A.; Burford, A.; Carvalho, D.; Izquierdo, E.; Fazal-Salom, J.; Taylor, K.R.; Bjerke, L.; Clarke, M.; Vinci, M.; Nandhabalan, M.; et al. Integrated Molecular Meta-Analysis of 1000 Pediatric High-Grade and Diffuse Intrinsic Pontine Glioma. Cancer Cell 2017, 32, 520-537.e5. [CrossRef] [PubMed]

23. Jones, C.; Perryman, L.; Hargrave, D. Paediatric and adult malignant glioma: Close relatives or distant cousins? Nat. Rev. Clin. Oncol. 2012, 9, 400-413. [CrossRef] [PubMed]

24. Kline, C.; Felton, E.; Allen, I.; Tahir, P.; Mueller, S. Survival outcomes of pediatric high-grade glioma: Results of a 20-year systematic review and meta-analysis. J. Neuro Oncol. 2017, 137, 103-110. [CrossRef]

25. McFaline-Figueroa, J.L.; Braun, C.J.; Stanciu, M.; Nagel, Z.D.; Mazzucato, P.; Sangaraju, D.; Cerniauskas, E.; Barford, K.; Vargas, A.; Chen, Y.; et al. Minor Changes in Expression of the Mismatch Repair Protein MSH2 Exert a Major Impact on Glioblastoma Response to Temozolomide. Cancer Res. 2015, 75, 3127-3138. [CrossRef]

26. Suwala, A.K.; Stichel, D.; Schrimpf, D.; Kloor, M.; Wefers, A.K.; Reinhardt, A.; Maas, S.L.N.; Kratz, C.P.; Schweizer, L.; Hasselblatt, M.; et al. Primary mismatch repair deficient IDH-mutant astrocytoma (PMMRDIA) is a distinct type with a poor prognosis. Acta Neuropathol. 2021, 141, 85-100. [CrossRef]

27. Shlien, A.; Campbell, B.B.; De Borja, R.; Alexandrov, L.B.; Merico, D.; Wedge, D.; van Loo, P.; Tarpey, P.S.; Coupland, P.; Behjati, S.; et al. Combined hereditary and somatic mutations of replication error repair genes result in rapid onset of ultra-hypermutated cancers. Nat. Genet. 2015, 47, 257-262. [CrossRef]

28. Gong, J.; Chehrazi-Raffle, A.; Reddi, S.; Salgia, R. Development of PD-1 and PD-L1 inhibitors as a form of cancer immunotherapy: A comprehensive review of registration trials and future considerations. J. Immunother. Cancer 2018, 6, 8. [CrossRef]

29. Le, D.T.; Uram, J.N.; Wang, H.; Bartlett, B.R.; Kemberling, H.; Eyring, A.D.; Skora, A.D.; Luber, B.S.; Azad, N.S.; Laheru, D.; et al. PD-1 Blockade in Tumors with Mismatch-Repair Deficiency. N. Engl. J. Med. 2015, 372, 2509-2520. [CrossRef]

30. Touat, M.; Li, Y.Y.; Boynton, A.N.; Spurr, L.F.; Iorgulescu, J.B.; Bohrson, C.L.; Cortes-Ciriano, I.; Birzu, C.; Geduldig, J.E.; Pelton, K.; et al. Mechanisms and therapeutic implications of hypermutation in gliomas. Nat. Cell Biol. 2020, 580, 517-523. [CrossRef]

31. Lombardi, G.; Idbaih, A.; Le Rhun, E.; Preusser, M.; Zagonel, V.; French, P. A New Landscape for Systemic Pharmacotherapy of Recurrent Glioblastoma? Cancers 2020, 12, 3775. [CrossRef] [PubMed]

32. Khasraw, M.; Reardon, D.A.; Weller, M.; Sampson, J.H. PD-1 Inhibitors: Do they have a Future in the Treatment of Glioblastoma? Clin. Cancer Res. 2020, 26, 5287-5296. [CrossRef] [PubMed]

33. Alharbi, M.; Mobark, N.A.; Almubarak, L.; Aljelaify, R.; AlSaeed, M.; Almutairi, A.; Alqubaishi, F.; Hussain, M.E.; Balbaid, A.A.O.; Marie, A.S.; et al. Durable Response to Nivolumab in a Pediatric Patient with Refractory Glioblastoma and Constitutional Biallelic Mismatch Repair Deficiency. Oncologist 2018, 23, 1401-1406. [CrossRef] [PubMed] 
34. Larouche, V.; Atkinson, J.; Albrecht, S.; LaFramboise, R.; Jabado, N.; Tabori, U.; Bouffet, E. Sustained complete response of recurrent glioblastoma to combined checkpoint inhibition in a young patient with constitutional mismatch repair deficiency. Pediatr. Blood Cancer 2018, 65, e27389. [CrossRef] [PubMed]

35. Chung, J.; Maruvka, Y.E.; Sudhaman, S.; Kelly, J.; Haradhvala, N.J.; Bianchi, V.; Edwards, M.; Forster, V.J.; Nunes, N.M.; Galati, M.A.; et al. DNA polymerase and mismatch repair exert distinct microsatellite instability signatures in normal and malignant human cells. Cancer Discov. 2020. [CrossRef]

36. Marabelle, A.; Fakih, M.; Lopez, J.; Shah, M.; Shapira-Frommer, R.; Nakagawa, K.; Chung, H.C.; Kindler, H.L.; Lopez-Martin, J.; Miller, W.H.; et al. Association of tumour mutational burden with outcomes in patients with advanced solid tumours treated with pembrolizumab: Prospective biomarker analysis of the multicohort, open-label, phase 2 KEYNOTE-158 study. Lancet Oncol. 2020, 21, 1353-1365. [CrossRef]

37. Samstein, R.M.; Lee, C.; Shoushtari, A.N.; Hellmann, M.D.; Shen, R.; Janjigian, Y.Y.; Barron, D.A.; Zehir, A.; Jordan, E.J.; Omuro, A.; et al. Tumor mutational load predicts survival after immunotherapy across multiple cancer types. Nat. Genet. 2019, 51, 202-206. [CrossRef]

38. Kamiya-Matsuoka, C.; Metrus, N.; Weathers, S.-P.; Ross, J.; Shaw, K.; Penas-Prado, M.; Loghin, M.; Alfaro-Munoz, K.; O’Brien, B.; Harrison, R.; et al. Is immuno-oncology therapy effective in hypermutator glioblastomas with somatic or germline mutations? Ann. Oncol. 2019, 30, v144. [CrossRef]

39. Johnson, A.; Severson, E.; Gay, L.; Vergilio, J.; Elvin, J.; Suh, J.; Daniel, S.; Covert, M.; Frampton, G.M.; Hsu, S.; et al. Comprehensive Genomic Profiling of 282 Pediatric Low- and High-Grade Gliomas Reveals Genomic Drivers, Tumor Mutational Burden, and Hypermutation Signatures. Oncologist 2017, 22, 1478-1490. [CrossRef]

40. Blank, C.U.; Haanen, J.B.; Ribas, A.; Schumacher, T.N. The “cancer immunogram”. Science 2016, 352, 658-660. [CrossRef]

41. Lombardi, G.; Barresi, V.; Indraccolo, S.; Simbolo, M.; Fassan, M.; Mandruzzato, S.; Simonelli, M.; Caccese, M.; Pizzi, M.; Fassina, A.; et al. Pembrolizumab Activity in Recurrent High-Grade Gliomas with Partial or Complete Loss of Mismatch Repair Protein Expression: A Monocentric, Observational and Prospective Pilot Study. Cancers 2020, 12, 2283. [CrossRef] [PubMed]

42. New Agent and Innovative Therapies Program (NAIT) Newsletter Early Phase Trials at SickKids. 2019. Available online: https://c17blog.files.wordpress.com/2019/09/nait_newsletter_september_2019.pdf (accessed on 15 January 2021).

Publisher's Note: MDPI stays neutral with regard to jurisdictional claims in published maps and institutional affiliations.

(C) 2021 by the authors. Licensee MDPI, Basel, Switzerland. This article is an open access article distributed under the terms and conditions of the Creative Commons Attribution (CC BY) license (http://creativecommons.org/licenses/by/4.0/). 